\title{
ISOLATION OF MICROORGANISMS OF CHEESE WHEY WITH LIPOLYTIC ACTIVITY FOR REMOVAL OF COD
}

\author{
ELIANE HERMES ${ }^{1}$, DAYANE C. DA ROCHA ${ }^{2}$, FÁBIO ORSSATTO ${ }^{3}$, \\ JULIANA F. R. LUCAS ${ }^{4}$, SIMONE D. GOMES ${ }^{5}$, LUCIANE SENE ${ }^{6}$
}

\begin{abstract}
The aim of this study was to isolate microorganisms that produce lipase and to assess the efficiency of COD removal in treatment of cheese whey under different operating conditions. The microorganisms were isolated from cheese whey and a commercial product; it was selected three microorganisms that obtained the best response to the lipolytic activity test through the enzyme index. Then, the microorganisms were inoculated in sterilized cheese whey samples, for two $\mathrm{pH}$ values (6.2 and 7.0), incubated at $35^{\circ} \mathrm{C}$ and $150 \mathrm{rpm}$ in shaker and the lipolityc activity and the efficiency of COD removal were measured in two time periods ( 24 and $48 \mathrm{~h}$ ). After incubation, it was observed that the treatments showed a good removal efficiency of COD for the pre-treatment and the isolated microorganism (S1) from the cheese whey showed the highest lipase production. Regarding the $\mathrm{pH}$ and time variables, there was not significant effect between the two evaluated factors. Among all treatments, $\mathrm{T} 2(\mathrm{~S} 1, \mathrm{pH} 7.0$ and $24 \mathrm{~h})$ obtained more enzyme production $\left(4.87 \mathrm{U} \mathrm{mL}^{-1}\right)$.
\end{abstract}

KEYWORDS: waste treatment, dairy industry, lipases.

\section{ISOLAMENTO DE MICRORGANISMOS DO SORO DE QUEIJO COM ATIVIDADE LIPÁSICA PARA REMOÇÃO DE DQO}

RESUMO: O objetivo deste estudo foi isolar microrganismos produtores de lipase e avaliar a eficiência de remoção de DQO no tratamento de soro de leite sob diferentes condições operacionais. Os microrganismos foram isolados a partir do soro de queijo e de um produto comercial, e foram selecionados os três microrganismos que obtiveram a melhor resposta no teste da atividade lipolítica, através do índice enzimático. Em seguida, inocularam-se os micro-organismos em amostras de soro de queijo esterilizado, para dois valores de $\mathrm{pH}\left(6,2\right.$ e 7,0), incubaram-se a $35^{\circ} \mathrm{C}$ e $150 \mathrm{rpm}$ em shaker e mensuram-se em dois períodos de tempo $(24$ e $48 \mathrm{~h})$ a atividade lipásica e a eficiência de remoção de DQO. Após a incubação, observou-se que os tratamentos apresentaram boa eficiência de remoção de DQO para o pré-tratamento, e o microrganismo (S1) isolado a partir do soro de queijo apresentou a maior produção de lipase. Com relação às variáveis pH e tempo, não houve efeito significativo entre os dois fatores avaliados. Entre todos os tratamentos aplicados, T2 ( $\mathrm{S} 1, \mathrm{pH} 7,0$ e 24 h) foi o que obteve maior produção enzimática $\left(4,87 \mathrm{U} \mathrm{mL}^{-1}\right)$.

PALAVRAS-CHAVE: tratamento de resíduos, indústria de laticínios, lipases.

\footnotetext{
${ }^{1}$ Doutoranda em Engenharia Agrícola (UNIOESTE) e professora da Universidade Federal do Paraná (UFPR), elianehermes@yahoo.com.br.

${ }^{2}$ Mestre em Engenharia Agrícola, Universidade Estadual do Oeste do Paraná (UNIOESTE). daycris_rocha@yahoo.com.br.

${ }^{3}$ Professor Mestre, Núcleo de Ciências Biológicas e Ambientais, Universidade Tecnológica Federal do Paraná (UTFPR-MD), orssatto@utfpr.edu.br.

${ }^{4}$ Doutoranda em Engenharia Agrícola, professora e servidora do Laboratório de Materiais (UNIOESTE). juliana.lucas@unioeste.br.

${ }^{5}$ Professora associada, Centro de Ciências Exatas e Tecnológicas, Universidade Estadual do Oeste do Paraná (UNIOESTE), simone.gomes@unioeste.br.

${ }^{6}$ Professora doutora, Centro de Ciências Médicas e Farmacêuticas, Universidade Estadual do Oeste do Paraná (UNIOESTE), luciane.sene@unioeste.br.
} 


\section{INTRODUCTION}

Most of the agro-industrial activities have as a limiting factor to production, the generation of wastes and effluents (BRUNO \& OLIVEIRA, 2008). In Brazil, agribusinesses stand out as major polluters, especially due to the large amount of waste rich in organic substances, nutrients, solids, oils and greases (MEES et al., 2009). In this category, the dairy industry has high potential as generator of waste (SILVA et al., 2006).

The effluents generated by dairy products contain lipids and proteins of low degradability in high amounts (CAMMAROTA \& FREIRE, 2006). The fraction of lipids is characterized by oils, greases, fats and fatty acids and, along with proteins and carbohydrates compose the main organic compounds of wastewater from various food industries. Residues rich in lipids are quite problematic from the environmental viewpoint, since these residues, when disposed in the environment, promote the formation of oil films on water surfaces, obstructing the diffusion of oxygen from the air and increasing the mortality of aquatic life.

Enzyme production is an expanding area of biotechnology, with approximately 4,000 known enzymes, and of these, about 200 are commercially used. The major drawback in the production of enzymes is their cost, which can be minimized by using agro-industrial residues as substrates for the cultivation of microorganisms (FERNANDES et al., 2007). Among the various enzymes that can be produced from solid state fermentation, the lipases are among the most studied ones.

The lipases can be produced through the use of agro-industrial residues (DAMASO et al., 2008) and are the enzymes (triacylglycerol hydrolase EC 3.1.1.3) that catalyze the hydrolysis of ester bonds of triacylglycerols producing diacylglycerides, monoacylglycerides, glycerol and fatty acids. This enzyme promotes the breaking of emulsions of esters, glycerines and fatty acids of long chain, which may be produced by microorganisms such as bacteria, fungi, and yeasts (PASTORE et al., 2003). Among the microorganisms known as good producers of lipase, are: Penicillium chrysogenum, Rhizopus oligosporus, Aspergillus niger, and the genus Pseudomonas, Bacillus, Burkholderia, among others.

Several studies show that, in addition to other applications, lipases can be used in pretreatment of waste rich in lipids, including effluents from industries of dairy products (ANDRETTA et al., 2007). Among the factors that affect the enzymatic process of fat removal of effluents, is cited the specificity of the enzyme to the substrate, the physico-chemical characteristics of the effluent, the $\mathrm{pH}$ of the reaction, the concentration and the composition of the waste.

The performance evaluation of treatment processes for removal of oil and grease is usually monitored by the percentage of fatty acid released in the reaction and by the reduction in effluent COD, as some authors have reported a positive correlation between COD and percentage of oils and fats (AZBAR \& YONAR, 2004). AQUINO et al. (2006) mention that the COD is a global parameter used as an indicator of organic content of the wastewater.

Given the above, the present study aimed to isolate microorganisms that produce lipase and evaluate the removal efficiency of COD and potential of lipase activity in the pre-treatment of cheese whey under different operating conditions.

\section{MATERIAL AND METHODS}

The experiment was conducted at the Laboratory of Environmental Sanitation of the State University of West Paraná (Laboratório de Saneamento Ambiental, Universidade Estadual do Oeste do Paraná - UNIOESTE) - Cascavel campus, located at Cascavel - state of Paraná (PR), Brazil. Therefore, it was used cheese whey collected from a dairy industry of the region, stored in PET bottles in a freezer $\left(-20^{\circ} \mathrm{C}\right)$ until the moment of use. To characterize this waste it was considered parameters and methodologies described in Table 1. 
TABLE 1. Parameters used for the characterization of cheese whey.

\begin{tabular}{lccc}
\hline \multicolumn{1}{c}{ Parameter } & Unity & Method & $\begin{array}{c}\text { Protocol } \\
\text { APHA (1998) }\end{array}$ \\
\hline Chemical Oxygen Demand (COD) & $\mathrm{mg} \mathrm{O}_{2} \mathrm{~L}^{-1}$ & Colorimetric & $5220-\mathrm{D}$ \\
pH & - & Potentiometric & $4500-\mathrm{H}^{+}-\mathrm{B}$ \\
Total Solids (TS) & $\mathrm{mg} \mathrm{L}^{-1}$ & Gravimetric & $2540-\mathrm{B}$ \\
Volatile Solids (VS) & $\mathrm{mg} \mathrm{L}^{-1}$ & Gravimetric & $2540-\mathrm{E}$ \\
Fixed Solids (FS) & $\mathrm{mg} \mathrm{L}^{-1}$ & Gravimetric & $2540-\mathrm{E}$ \\
Lipids (\%) & $\mathrm{mg} \mathrm{L}^{-1}$ & Soxhlet extraction & $5520-\mathrm{D}$ \\
Kjeldahl Total Nitrogen $\left(\mathrm{KTN}^{-1}\right)$ & $\mathrm{mg} \mathrm{NL}^{-1}$ & Semimicro-Kjeldahl & $4500-\mathrm{N}_{\text {org }}-\mathrm{B}$ \\
Ammoniacal Nitrogen $\left(\mathrm{NH}_{3} \mathrm{~N}\right)$ & $\mathrm{mg} \mathrm{NL}^{-1}$ & Colorimetric & $4500-\mathrm{N}-\mathrm{NH}_{3}-\mathrm{F}$ \\
\hline
\end{tabular}

Initially, it was proceeded the selection of microorganisms suitable for the process of hydrolysis of lipids. For this purpose, it was carried out the isolation of microorganisms in the cheese whey, by inoculating cheese whey through the streak-plate technique on Petri dishes with a culture medium consisting of yeast extract (1\%), peptone (2\%), lactose (2\%) and agar (1.5\%), being incubated at $30{ }^{\circ} \mathrm{C}$ for $48 \mathrm{~h}$.

Then, it was tested the lipolytic activity of colonies of isolated microorganisms. For this, it was inoculated the microorganism in the center of a Petri dish that contained the culture medium composed of peptone $(1 \%)$, sodium chloride $(0.5 \%)$ and agar $(2 \%)$. To this medium it was added $1 \%$ of Tween-20 (sorbitan monolaurate). It was incubated for 12 days at $28{ }^{\circ} \mathrm{C}$ and, according to the methodology described by HANKIN \& ANAGNOSTAKIS (1975), it was calculated the Enzyme Index $(\mathrm{EI}=$ diameter of colony + halo/colony diameter $)$ of the colonies.

Likewise, it was proceeded the isolation of microorganisms and the test of lipolytic activity from a commercial product (BIOL 2000 liquid, from BioPlus Company) indicated for the treatment of effluents with a high content of lipids.

It was obtained six microorganisms isolated from cheese whey and three from the commercial product; from these, the ones that showed the highest EI after evaluation of lipolytic activity, were selected for the subsequent step, being two microorganisms from cheese whey (S1 and S2) and one from the commercial product (B1). These were observed for identification of morphology in an optical microscope and Gram staining if necessary.

The two microorganisms selected from cheese whey correspond to a gram+ bacteria coccus (S1) and a fungus (S2) and the microorganism isolated from the commercial product was also a gram+ bacteria coccus (B1).

After the selection, the selected microorganisms were transferred to a liquid culture medium composed of yeast extract (1\%), peptone (2\%) and lactose $(2 \%)$ and incubated at $30{ }^{\circ} \mathrm{C}$ for $24 \mathrm{~h}$, to prepare the inoculum. After growth, the material was centrifuged at $2000 \mathrm{rpm}$ for 15 minutes and the precipitate (biomass) was washed with sterile distilled water.

Finally, $0.5 \mathrm{~mL}$ of the inoculum at an initial concentration of cells corresponding to the optical density $(600 \eta \mathrm{m})$ of 0.05 , was distributed in erlenmeyer flasks with $50 \mathrm{~mL}$ of sterilized cheese whey at two pH levels (6.2 and 7.0) and incubated in a shaker at $35^{\circ} \mathrm{C}, 150 \mathrm{rpm}$ and two times (24 and 48h). In Table 2 are disposed the 12 treatments applied, performed in triplicate.

After the reaction time, the samples were centrifuged under the conditions specified above for separation of the biomass, which was discarded. The supernatant was characterized for the parameters $\mathrm{pH}, \mathrm{COD}$ and lipolytic activity. 
TABLE 2. Distribution of the 12 treatments applied in the study.

\begin{tabular}{cccc}
\hline Treatment & Microorganism & $\mathrm{pH}$ & Time (h) \\
\hline 1 & S1 & 6.2 & 24 \\
2 & S1 & 7.0 & 24 \\
3 & S2 & 6.2 & 24 \\
4 & S2 & 7.0 & 24 \\
5 & B1 & 6.2 & 24 \\
6 & B1 & 7.0 & 24 \\
7 & S1 & 6.2 & 48 \\
8 & S1 & 7.0 & 48 \\
9 & S2 & 6.2 & 48 \\
10 & S2 & 7.0 & 48 \\
11 & B1 & 6.2 & 48 \\
12 & B1 & 7.0 & 48 \\
\hline
\end{tabular}

The determination of the lipolytic activity was performed by titrimetric method according to DELLMORA-ORTIZ et al. (1997). For this, it was used $5 \mathrm{~mL}$ of olive oil emulsion $20 \%(\mathrm{v} / \mathrm{v})$ in Arabic gum $5 \%(\mathrm{p} / \mathrm{v})$ (substrate) and $2 \mathrm{~mL}$ of potassium phosphate plug $50 \mathrm{mM}, \mathrm{pH}$ 7.0. The test was performed in shaker with $240 \mathrm{rpm}$ agitation at $37{ }^{\circ} \mathrm{C}$ and initiated by the addition of $3 \mathrm{~mL}$ of the enzyme preparation, previously heated to the test temperature. After 15 minutes of incubation, the reaction was stopped by the addition of $10 \mathrm{~mL}$ of a mixture of ethanol and acetone $(1: 1)$.

The fatty acids formed by the hydrolysis of the triglycerides present in the emulsion were quantified by titration with $0.025 \mathrm{~N} \mathrm{NaOH}$ using phenolphthalein as an indicator. It was also used a white, containing $3 \mathrm{~mL}$ of distilled water. The lipolytic activity was calculated according to equation (1) expressed in micro moles of fatty acid, per minute of reaction, per milliliter of sample according to DELLMORA-ORTIZ et al. (1997).

$$
\text { Lipolytic Activity }\left(U \cdot m L^{-1} * \min ^{-1}\right)=\frac{\left(V_{a}-V_{b}\right) * N * 1000}{V_{c} * T}
$$

in which,

$\mathrm{V}_{\mathrm{a}}-\mathrm{NaOH}$ volume spent in the titration of sample, $\mathrm{mL}$;

$\mathrm{V}_{\mathrm{b}}-\mathrm{NaOH}$ volume spent in the titration of white, $\mathrm{mL}$;

$\mathrm{N}$ - normality of $\mathrm{NaOH}$, equal to $0.025 \mathrm{~N}$;

$\mathrm{V}_{\mathrm{c}}$ - used volume of sample, $\mathrm{mL}$, and

$\mathrm{T}$ - time of reaction, min.

\section{RESULTS AND DISCUSSION}

\section{Characterization of cheese whey}

Table 3 presents the initial characterization of the cheese whey.

TABLE 3. Initial characterization of the cheese whey.

\begin{tabular}{ccc}
\hline Parameter & Unity & Mean Value \\
\hline $\mathrm{pH}$ & - & 6.20 \\
COD & $\mathrm{mg} \mathrm{L}^{-1}$ & 85310.00 \\
Total solids & $\mathrm{mg} \mathrm{L}^{-1}$ & 64320.00 \\
Volatile solids & $\mathrm{mg} \mathrm{L}^{-1}$ & 55290.00 \\
Fixed solids & $\mathrm{mg} \mathrm{L}^{-1}$ & 9030.00 \\
Lipid content & $\%$ & 1.08 \\
Total nitrogen & $\mathrm{mg} \mathrm{N} \mathrm{L}^{-1}$ & 538.72 \\
Ammoniacal nitrogen & $\mathrm{mg} \mathrm{N} \mathrm{L}^{-1}$ & 55.94 \\
\hline
\end{tabular}


The $\mathrm{pH}$ values found in the used waste were similar to those reported in other studies to sweet whey (pH 6.0-7.0). Regarding the values of COD, SILVA (2006) characterized cheese whey and obtained COD values in the range of 53 to $100 \mathrm{~g} \mathrm{~L}^{-1}$, similar to that described in Table 3 . The lipid content is usually in the range of 0.4 to $0.5 \%$ and the determined in this study was higher, possibly due to evaporation of water from the whey storage tank of the Cooperative.

\section{Treatments evaluation}

Table 4 shows the distribution of $\mathrm{pH}$ data before and after the cultivation of microorganisms under the tested conditions.

TABLE 4. Average $\mathrm{pH}$ values obtained for the tested treatments.

\begin{tabular}{ccl}
\hline Treatment & Initial $\mathrm{pH}$ & $\mathrm{pH}$ \\
\hline 7 & 6.2 & $4.3 \mathrm{~A}$ \\
8 & 7.0 & $4.4 \mathrm{Ab}$ \\
1 & 6.2 & $4.5 \mathrm{Abc}$ \\
2 & 7.0 & $4.6 \mathrm{Abcd}$ \\
11 & 6.2 & $5.0 \mathrm{Bcde}$ \\
12 & 7.0 & $5.1 \mathrm{Cde}$ \\
3 & 6.2 & $5.1 \mathrm{Cde}$ \\
5 & 6.2 & $5.1 \mathrm{Cde}$ \\
4 & 7.0 & $5.2 \mathrm{Cde}$ \\
9 & 6.2 & $5.2 \mathrm{Cde}$ \\
10 & 7.0 & $5.2 \mathrm{De}$ \\
6 & 7.0 & $5.6 \mathrm{E}$ \\
\hline
\end{tabular}

*the averages followed by the same letter do not differ significantly by the Tukey test at $5 \%$ of significance.

The $\mathrm{pH}$ values decreased after cultivation of microorganisms due to the increase of volatile fatty acids, mainly by the production of lactic acid during the fermentation process. Table 5 describes the analysis of variance of $\mathrm{pH}$ final values obtained after the treatments.

TABLE 5. Summary of the analysis of variance to obtain the $\mathrm{F}$ values of $\mathrm{pH}$ final values in relation to the applied treatments.

\begin{tabular}{cccccc}
\hline FV & GL & SQ & QM & Fc & Pr > Fc \\
\hline Treatment & 11 & 5.09 & 1.46 & 8.39 & 0.00 \\
Error & 24 & 1.32 & 0.05 & & \\
Total & 35 & 6.41 & & & \\
CV $(\%)$ & 4.74 & & & \\
General Mean & 4.95 & Number of observations: 36 & & \\
\hline
\end{tabular}

Using descriptive statistics, it can be seen that for $\mathrm{pH}$, the treatments showed a low coefficient of variation $(4.74 \%)$, which indicates homogeneous data, reflecting very similar results (PIMENTEL GOMES, 2000). At 5\% significance level, $\mathrm{F}=8.39>\mathrm{F}(11,24,5 \%)=2.22$, which implies the rejection of the hypothesis $\mathrm{H}_{0}$, concluding that the treatment means differ. To perform the statistical analysis it was applied the Tukey test at 5\% significance (Table 4).

By the Tukey test, it can be observed that the treatments applied to the microorganism S1 (treatments 1,2, 7 and 8), obtained the highest decreases in $\mathrm{pH}$ values.

Table 6 presents the analysis of variance (ANOVA) having as response variable the lipolytic activity and as a factor of change the treatments applied. 
TABLE 6. Summary of the analysis of variance to obtain the F values of lipolytic activity in relation to the applied treatments.

\begin{tabular}{cccccc}
\hline FV & GL & SQ & QM & Fc & Pr > Fc \\
\hline Treatment & 11 & 17.02 & 1.55 & 143.59 & 0.00 \\
Error & 24 & 0.26 & 0.01 & & \\
Total & 35 & 17.28 & & & \\
CV $(\%)$ & 2.88 & & & & \\
General Means & 3.69 & Number of observations: 36 & & \\
\hline
\end{tabular}

At $5 \%$ level of significance, $\mathrm{F}=143.59>\mathrm{F}_{(11,24,5 \%)}=2.22$, which implies that the hypothesis $\mathrm{H}_{0}$ was rejected, indicating that the treatments were statistically different, interfering with the production of lipase. To perform the statistical analysis it was applied the Tukey test at 5\% significance (Table 7).

The microorganism S1 was superior for the production of lipase, detected by measuring the activity in the titration test. The highest average production of lipase was obtained in treatment 2 which worked at $\mathrm{pH} 7.0$ and $24 \mathrm{~h}$ of reaction time. The microorganism with the smallest lipase activity was B1 in treatment 6 (pH 7.0 and 24 hours).

TABLE 7. Lipolytic activity values obtained in the evaluated treatments.

\begin{tabular}{cc}
\hline Treatment & Lipolytic activity $\left(\mathrm{U} \mathrm{mL}^{-1} \mathrm{~min}^{-1}\right)$ \\
\hline 6 & $2.76 \mathrm{~A}$ \\
9 & $2.78 \mathrm{~A}$ \\
4 & $3.04 \mathrm{Ab}$ \\
10 & $3.21 \mathrm{Bc}$ \\
3 & $3.29 \mathrm{Bcd}$ \\
11 & $3.31 \mathrm{Bcd}$ \\
12 & $3.48 \mathrm{Cd}$ \\
5 & $3.54 \mathrm{D}$ \\
8 & $3.91 \mathrm{E}$ \\
7 & $4.36 \mathrm{~F}$ \\
1 & $4.76 \mathrm{G}$ \\
2 & $4.87 \mathrm{G}$ \\
\hline
\end{tabular}

* The averages followed by the same letter do not differ significantly by the Tukey test at $5 \%$ of significance.

Figure 1 shows the data distribution of lipolytic activity as a function of reaction time for the treatments.

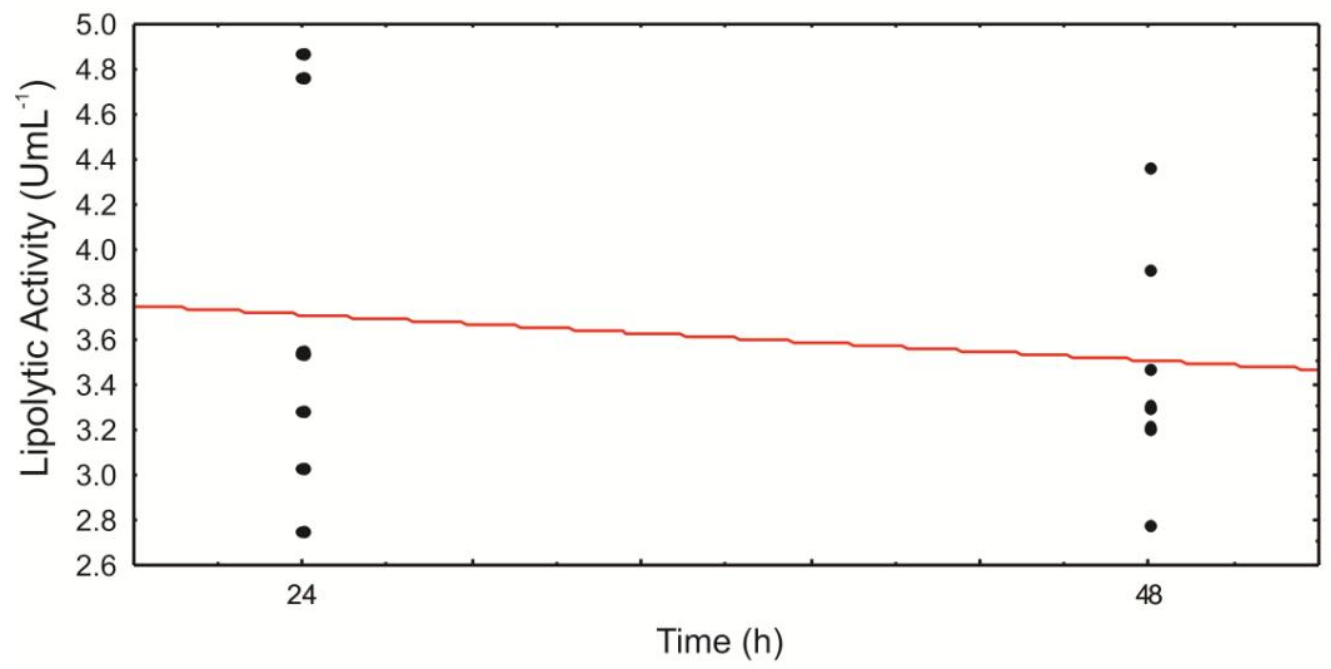

FIGURE 1. Distribution of lipolytic activity data versus reaction time. 
The $\mathrm{pH}$ value of 6.2 present a higher lipase production, with only $0.13 \mathrm{U} \mathrm{mL}^{-1} \mathrm{~min}^{-1}$ superior than the enzymatic production obtained at $\mathrm{pH}$ 7.0. This may be favorable to the process, because it will not be necessary adjust the $\mathrm{pH}$ in the reaction, generating savings in the lipase process.

Considering the conditions of $\mathrm{pH}$ and time, the variation was not significant compared to the lipolytic activity. The time of $24 \mathrm{~h}$ showed better results $\left(3.71 \mathrm{U} \mathrm{mL}^{-1} \mathrm{~min}^{-1}\right)$ compared to the period of $48 \mathrm{~h}\left(3.51 \mathrm{U} \mathrm{mL}^{-1} \mathrm{~min}^{-1}\right)$, perhaps justified by the subsequent enzyme inactivation.

In general, the average lipase production was $3.61 \mathrm{U} \mathrm{mL}^{-1} \mathrm{~min}^{-1}$. RAJENDRAN \& THANGAVELU (2009) evaluated the lipase production by Rhizopus arrhizus in a mixture of components and found a maximum value of $3.98 \mathrm{U} \mathrm{mL}^{-1}$. BROZZOLI et al. (2009) produced lipase using wastewater from industry olive oil as a culture medium for Candida cylindracea and obtained values that reached $20.4 \mathrm{U} \mathrm{mL}^{-1}$.

Table 8 shows the distribution of percent values of removal efficiency of COD, after cultivation of microorganisms in the tested conditions. Using descriptive statistics, it was observed that only two treatments (1 and 6) presented coefficient of variation much higher than the recommended, which is $10 \%$, indicating that these presented heterogeneous data (PIMENTEL GOMES, 2000). Treatment 6, consequently, obtained high values for both standard deviation and variance, when compared to the other treatments.

TABLE 8. COD removal efficiency values, for the evaluated treatments.

\begin{tabular}{cccrc}
\hline Treatment & $\begin{array}{c}\text { Removal Efficiency of } \\
\text { COD }(\%)\end{array}$ & $\begin{array}{c}\text { Standard } \\
\text { Deviation }\end{array}$ & $\begin{array}{c}\text { Variance } \\
\text { Coefficient of Variation } \\
(\%)\end{array}$ \\
\hline 1 & $12.14 \mathrm{~d}$ & 9.12 & 83.21 & 75.14 \\
2 & $33.54 \mathrm{abc}$ & 2.07 & 4.29 & 6.18 \\
3 & $39.40 \mathrm{ab}$ & 2.91 & 8.45 & 7.38 \\
4 & $25.62 \mathrm{c}$ & 0.83 & 0.68 & 3.23 \\
5 & $44.96 \mathrm{a}$ & 0.83 & 0.68 & 1.84 \\
6 & $32.70^{* * *}$ & 36.50 & 1329.70 & 111.67 \\
7 & $29.44 \mathrm{bc}$ & 2.07 & 4.29 & 7.04 \\
8 & $38.22 \mathrm{ab}$ & 1.24 & 1.55 & 3.26 \\
9 & $35.88 \mathrm{abc}$ & 0.41 & 0.17 & 1.14 \\
10 & $37.05 \mathrm{abc}$ & 0.41 & 0.17 & 1.11 \\
11 & $43.20 \mathrm{a}$ & 0.83 & 0.68 & 1.91 \\
12 & $40.86 \mathrm{ab}$ & 0.83 & 0.70 & 2.04 \\
Mean & 34.42 & 4.84 & 119.55 & 18.49 \\
\hline
\end{tabular}

* The averages followed by the same letter do not differ significantly by the Tukey test at 5\% of significance. ** Treatment not considered in the test of comparison of means due to the high $\mathrm{CV}$.

Through the comparison test between the means of the treatments, it was noted that even with a high variation between the averages (12.4 to $44.96 \%$ ) there was no statistical difference at $5 \%$ probability, between treatments, possibly due to the high coefficient of variation (111.67\%) occurred in treatment 6 .

Considering the above, we decided to analyze the results of removal efficiency of COD excluding the treatment 6 , observing then, a variation between the averages obtained in 4 levels (Table 8), being the treatment 1 , the treatment with lower efficiency of COD removal and statistically different from all other treatments.

After the incubation, it was found that the treatments presented a good removal efficiency of COD for the pre-treatment. On average, the treatments with the highest percentage of COD removal were those who used the microorganism of the commercial product (treatments 5; 11 and 12). However, treatments of the microorganisms originating from cheese whey also presented good 
results (treatments $2 ; 3 ; 8 ; 9$ and 10), with the exception of one treatment that received only $12.14 \%$ of removal.

LOPERENA et al. (2009), applying different microorganisms to treat waste from a dairy industry, obtained means of removal between 34 and $44 \%$ in a time of $48 \mathrm{~h}$ with the application of microorganism Bacillus sp., values similar to the obtained in some treatments used in this study.

LOPERENA et al. (2007) studied the treatment of dairy wastewater, inoculating a commercial product and the sludge of a pond of dairy effluent treatment, obtaining values of COD removal efficiency of 78 and $81 \%$, respectively, which were above those obtained in this study.

DURLI (2007), after his experiment concluded that even optimizing the treatment for a standardized effluent sample studying controlled variables $(\mathrm{pH}$, temperature, enzyme concentration), the actual process of generation and effluent treatment by enzymatic hydrolysis of other variables must be considered, such as performing a kinetics of removal of oils and greases in order to determine the best time to interrupt the process.

\section{CONCLUSIONS}

From the results, it can be seen that different microorganisms actively interfere in the efficiency of enzyme production. The S1 microorganism isolated from whey cheese, showed the highest lipase production for all treatments compared to other microorganisms tested.

With respect to $\mathrm{pH}$ and time, there was no significant effect between the two evaluated factors. Comparing all the treatments, treatment $2(\mathrm{~S} 1, \mathrm{pH} 7.0$ and $24 \mathrm{~h})$ showed the highest lipolytic activity.

Finally, it can be observed that the microorganisms isolated from dairy waste can be used in pre-treatment in terms of COD removal.

\section{ACKNOWLEDGEMENT}

To the Coordination for the Improvement of Higher Education Personnel (Coordenação de Aperfeiçoamento de Pessoal de Nível Superior - CAPES) and the National Council of Technological and Scientific Development (Conselho Nacional de Desenvolvimento Científico e Tecnológico - CNPq) for the financial support.

\section{REFERENCES}

ANDRETTA, V.; DAMSCHI JUNIOR, L.I.; ONOFRE, S.B. Seleção de fungos filamentosos produtores de lípases de águas residuárias de lacticínios. Biology \& Health Journal, Dois Vizinhos, v.1, p.77-84, 2007.

APHA. AMERICAN PUBLIC HEALTH ASSOCIATION. Standard methods for the examination of water and wastewater, Washington, 1998.

AQUINO, S.F.; SILVA, S.Q.; CHERNICHARO, C.A.L. Considerações práticas sobre o teste de demanda química de oxigênio (DQO) aplicado a análise de efluentes anaeróbios. Engenharia Sanitária e Ambiental, Rio de Janeiro, v.11, n.4, p.295-304, 2006.

AZBAR, N.; YONAR, T. Comparative evaluation of a laboratory and full-scale treatment alternatives for the vegetable oil refining industry wastewater. Process Biochemistry, Vandoeuvre-les-Nancy, v.39, p.869-875, 2004.

BROZZOLI, V.; CROGNALE, S.; SAMPEDRO, I.; FEDERICI, F.; D’ANNIBALE, A.; PETRUCCIOLI, M. Assessment of olive-mill wastewater as a growth medium for lipase production by Candida cylindracea in bech-top reactor. Bioresource Technology, Fayetteville, v.100, p.33953402, 2009. 
BRUNO, M.; OLIVEIRA, R. A. Tratamento anaeróbio de águas residuárias do beneficiamento de café por via úmida em reatores UASB em dois estágios. Engenharia Agrícola, Jaboticabal, v.28, n.2, p.364-377, abr./jun. 2008.

CAMMAROTA, M.C.; FREIRE, D.M.G. A review of hydrolytic enzymes in the treatment of wastewater with high oil grease content. Bioresource Technology, Fayetteville, v.97, n.17, p.21952210, nov., 2006.

DAMASO, M.C.T.; PASSIANOTO, M.A.; FREITAS, S.C.; FREIRE, D.M.G.; LAGO, R.C.A.; COURI, S. Utilization of agroindustrial residues for lipase production by solid-state fermentation. Brazilian Journal of Microbiology, São Paulo, v.39, n.4, p.676-681, dez. 2008.

DELLAMORA-ORTIZ, G.M.; MARTINS, R.C.; ROCHA, W.L.; DIAS, A.P. Activity and stability of a Rzizomucor miehei lipase in hydrophonic media. Biotechnology Applied Biochemistry, Indianapolis, v.26, p.111-116, 1997.

DURLI, E. Tratamento de efluente de indústria de laticínios utilizando lípases de Burkholderia cepacia LTEB11. 2007. 111 f. Dissertação (Mestrado em Química) - Universidade Federal do Paraná, Curitiba, 2007.

FERNANDES, M.L.M.; SAAD, E.B.; MEIRA, J.A.; RAMOS L.P.; MITCHELL, D.A.; KRIEGER, N. Esterification and transesterification reactions catalysed by addition of fermented solids to organic reaction media. Journal of Molecular Catalysis B: Enzymatic, Delft, v.44, p.8-13, 2007.

HANKIN, L. ANAGNOSTAKIS, S. G. The use of solid media for detection of enzyme production by fungi. Mycologia, Bronx, v.67, p.597-607, 1975.

LOPERENA, L.; FERRARI, D.; DÍAZ, A. L.; INGOLD, G.; PÉREZ, L. V.; CARVALLO, F.; TRAVERS, D.; MENS, R. J.; LAREO, C. Isolation and selection of native microorganisms for the aerobic treatment of simulated dairy wastewaters. Bioresource Technology, Fayetteville, v.100, p.762766, 2009.

LOPERENA, L.; FERRARI, M. D.; SARAVIA, V.; MURRO, D.; LIMA, C.; FERRANDO, L.; FERNÁNDEZ, A.; LAREO, C. Performance of a commercial inoculum for the aerobic biodegradation of a high fat content dairy wastewater. Bioresource Technology, Fayetteville, v.98, p.1045-1051, 2007.

MEES, J.B.R.; GOMES, S.D.; VILAS BOAS, M.A.; FAZOLO, A.; SAMPAIO, S.C. Removal of organic matter and nutrients from slaughterhouse wastewater by using Eichhornia crassipes and evaluation of the generated biomass composting. Engenharia Agrícola, Jaboticabal, v.29, n.3, p.466-473, jul./set. 2009.

PASTORE, G.M.; COSTA, V.S.R.; KOBLITZ, M.G.B. Purificação parcial e caracterização bioquímica de lipase extracelular produzida por nova linhagem de Rhizopus sp. Ciência e Tecnologia de Alimentos, Campinas, v.23, p.135-140, 2003.

PIMENTEL GOMES, F. Curso de estatística experimental. 14. ed. Piracicaba: Degaspari, 2000. $477 \mathrm{p}$.

RAJENDRAN, A.; THANGAVELU, V. Statistical experimental design for evaluation of medium components for lipase production by Rhizopuz arrhizus. LWT - Food Science and Technology, Zürich, v.42, p.985-992, 2009.

SILVA, D.J.P. Diagnóstico do consumo de água e da geração de efluentes em uma indústria de laticínios e desenvolvimento de um sistema multimídia de apoio. 2006. $101 \mathrm{f}$. Tese (Doutorado em Ciência e Tecnologia de Alimentos) - Universidade Federal de Viçosa, Viçosa, 2006.

SILVA, L.V.B.D.; RODRIGUES, B.H.N.; LIMA, V.L.A.; SANTOS, J.S. Plano de controle ambiental da estação de tratamento dos efluentes de uma indústria de laticínios. Revista Educação Agrícola Superior, Brasília, v.21, n.2, p.48-49, jul./dez. 2006. 